\title{
ABSTRAK \\ MODEL PEMBELAJARAN SAINS BERBASIS INKUIRI LABORATORIUM KONSEP ASAM BASA DALAM MENINGKATKAN KONSEP, BERPIKIR KREATIF, DAN KETERAMPILAN PROSES SISWA SMP
}

Surati, Dosen Prodi Pendidikan Biologi IAIN Ambon, 081231226671,

E-mail: intap@yahoo.co.id

Hasil analisis data menunjukkan pembelajaran ini dapat meningkatkan pemahaman konsep pada setiap kelompok kemampuan siswa, mengembangkan kemampuan berpikir kreatif dengan hasil tertinggi pada aspek membangun konsep di atas pengetahuan yang telah ada pada diri siswa dan terendah pada aspek memilih hal-hal yang mungkin tidak relevan, serta keterampilan proses sains mengatasi kurangnya waktu pembelajaran, bagian-bagian pembelajaran tertentu dapat dilaksanakan di luar jam kelas.

\section{Kata Kunci: Pembelajaran Sains, Inkuiri Laboratorium}

Sains adalah suatu ilmu pengetahuan eksperimental, observasional, dan berkiblat pada laboratorium., oleh karena itu pelajaran sains yang efektif seharusnya berpusat pada laboratorium, bukan berpusat pada buku pelajaran. Inkuiri dapat diartikan sebagai proses yang ditempuh manusia untuk mendapatkan informasi atau untuk memecahkan suatu permasalahan Pandangan inkuri muncul dari National Science Education Standards (NSES) (1996). Salah satu area dalam standar pengajaran sains dan standar pengembangan profesional adalah pengembangan program pembelajaran berbasis inkuiri dan pembelajaran konten sains melalui inkuiri. NSES mengesahkan kurikulum sains yang melibatkan siswa secara aktif dalam sains menggunakan pendekatan inkuiri. Pendekatan ini telah mengubah fokus pendidikan sains dari penghafalan konsep-konsep dan faktafakta dalam mata pelajaran ke belajar berdasar inkuiri, selanjutnya siswa mencoba menjawab untuk memahami dan/atau memecahkan suatu masalah (NRC, 1996 \& 1999).

Pembelajaran inkuiri didefinisikan sebagai pembelajaran yang mempersiapkan situasi bagi anak untuk melakukan eksperimen sendiri; dalam arti luas ingin melihat apa yang terjadi, ingin 
melakukan sesuatu, ingin menggunakan simbol-simbol dan mencari jawaban atas pertanyaan sendiri, menghubungkan penemuan yang satu dengan penemuan yang lain, membandingkan yang ditemukan sendiri dengan yang ditemukan orang lain (Piaget dalam Sund dan Trowbridge: 1973). Pada hakekatnya, kegiatan apapun yang dilakukan di laboratorium, mengelola laboratorium, khususnya guru, harus selalu memperhatikan tujuan-tujuan instruksional yang antara lain diharapkan siswa dapat: 1) Mengembangkan keterampilan dalam pengamatan, pecatatan data, pengukuran dan manipulasi alat yang diperlukan serta pembuatan alat-alat yang sederhana; 2) Bekerja dengan teliti dan cermat dalam mencatat dan menyusun laporan hasil percobaannya secara jelas dan objektif/jujur; 3) Bekerja secara teliti dan cermat serta mengenal batasbatas kemampuannya dalam pengukuranpengukuran; 4) Mengembangkan kekuatan-kekuatan penalarannya secara kritis; 5) Memperdalam pengetahuan inkuiri dalam pemahaman terhadap cara pemecahan masalah; 6) Mengembangkan sikap ilmiah; 7) Memahami, memperdalam dan menghayati IPA yang dipelajarinya; 8) Dapat mendesain dan melaksanakan percobaan lebih lanjut dengan menggunakan alat dan bahan yang sederhana. (Moh. Amien,1987).

Pedagogi (cara mengajar) menganjurkan untuk suatu pendekatan inkuiri, yang melibatkan siswa secara aktif menggunakan proses sains dan kemampuan berpikir kritis dan kreatif seperti mereka menemukan jawaban atas pertanyaan-pertanyaan yang diajukan (Hebrank, 2000). Sementara itu, Hodson (1996) mengemukakan bahwa pembelajaran berbasis kegiatan laboratorium dapat meningkatkan perkembangan siswa melalui: 1) proses belajar sains (learning science); 2) belajar tentang sains (learning about science); dan 3) belajar 'mengerjakan' sains (doing science). Berdasarkan pandanganpandangan tersebut yang dapat mensintesiskan suatu pendekatan yang akan diambil dalam penelitian ini yaitu pendekatan inkuiri laboratorium.

Dalam pendekatan inkuiri laboratorium, konsep-konsep yang dipraktikumkan dirancang sesuai materi konsep dan relevan dengan kehidupan sehari-hari siswa. (Arief Sidharta, 2010). 
Pengalaman siswa dalam situasi keterampilan berpikir kreatif, dan laboratorium seharusnya menjadi bagian keterampilan proses sains siswa SMP. intergral dari mata pelajaran sains (Hofstein dan Lunetta, 1982). Kegiatan laboratorium mempunyai peranan penting dalam pengajaran sains. Romey (1978) berpendapat bahwa kegiatan laboratorium yang berorientasi sebagai sarana untuk menjelaskan keterangan guru atau buku pelajaran sangat berlawanan dengan sains sebenarnya. Sains merupakan ilmu pengetahuan eksperimental, observasional, dan berkiblat pada laboratorium., oleh karena itu pelajaran sains yang efektif seharusnya berpusat pada laboratorium, bukan berpusat pada buku pelajaran.

Pentingnya menghubungkan materi dengan kehidupan sehari-hari sebagai landasan pengembangan pendekatan pembelajaran ditujukan untuk: 1) memotivasi belajar siswa; 2) melatih berpikir kritis, kreatif, analitik; 3) mengembangkan keterampilan proses dan keterampilan sosial. Rancangan pembelajaran yang disusun ini, selain ditujukan untuk melihat efektivitas pembelajaran Sains, juga untuk meningkatkan pemahaman terhadap konsep asam basa, mengembangkan

\section{METODE PENELITIAN}

Penelitian ini difokuskan pada pengembangan pembelajaran Sains (khususnya kimia materi asam basa) dengan tujuan dapat meningkatkan penguasaan konsep, keterampilan berpikir kreatif dan keterampilan proses sains siswa. Subyek dalam penelitian ini, ditetapkan siswa dari salah satu kelas VIII (satu kelas sebanyak 40 orang siswa) semester genap tahun pelajaran 2014/2015. Siswa dikelompokkan menjadi tiga kelompok yaitu kelompok yang mempunyai kemampuan tinggi, kemampuan sedang dan kemampuan rendah. Kategori kemampuan tersebut didasarkan pada nilai rata-rata ulangan harian siswa pada mata pelajaran sainskimia kelas VIII semester 1.

Prosedur penelitian melalui 3 tahapan yaitu: 1) Tahap Persiapan . Pada tahap ini dimulai dengan merancang model pembelajaran, evaluasi, serta angket siswa. Pembuatan model pembelajaran untuk meningkatkan penguasaan konsep, keterampilan berpikir kreatif dan keterampilan proses sains 
dimulai dengan mengkaji konsep-konsep sains-kimia yang sesuai untuk siswa SMP. Selanjutnya dibuat peta konsep dari konsep-konsep yang ada, dan langkah terakhir pada tahap ini adalah membuat model pembelajaran. 2)Tahap Pelaksanaan. Pada tahap ini dilakukan penerapan model pembelajaran yang telah dibuat. Dalam penerapan model pembelajaran tersebut dilakukan oleh guru kelas, sedangkan peneliti dibantu dua rekan sejawat bertindak sebagai observer yang mengamati kegiatan-kegiatan guru dan siswa selama proses pembelajaran berlangsung. 3). Tahap Analisis. Setelah implementasi model pembelajaran selesai, data yang telah terkumpul dianalisis dan diolah secara statistik untuk data kuantitatif dan secara deskriptif untuk data kualitatif. Instrumen yang digunakan dalam penelitian ini adalah:

1. Lembar Tes Tertulis. Lembar tes tertulis berisi 20 butir soal yang bertujuan untuk mengukur penguasaan konsep asam basa, mengukur keterampilan berpikir kreatif dan keterampilan proses sains, baik sebelum maupun sesudah pembelajaran.
2. Lembar Kegiatan Siswa (LKS). Lembar kegiatan siswa digunakan untuk membekali pemahaman konsep, keterampilan berpikir kreatif siswa dan keterampilan proses sains.

3. Angket. Angket digunakan untuk mengetahui tanggapan siswa mengenai model pembelajaran yang diimplementasikan, mengetahui pendapat siswa terhadap pembelajaran sains kimia khususnya pokok bahasan asam basa.

4. Wawancara. Pedoman wawancara digunakan untuk memperoleh tanggapan guru dan siswa terhadap model pembelajaran yang digunakan. Wawancara dilakukan terhadap guru dan siswa secara terpisah, dilakukan setelah pembelajaran.

5. Observasi. Pedoman observasi digunakan untuk melihat guru menerapkan model pembelajaran yang dibuat oleh peneliti. Pelaksanaan observasi dilakukan oleh peneliti sebanyak tiga kali pertemuan pembelajaran.

Data hasil penelitian yang diperoleh berupa data kuantitatif, yaitu data yang diperoleh dari hasil pretes dan postes dianalisis menggunakan uji $\mathrm{t}$, dan 
data kualitatif yaitu data yang diperoleh dari tanggapan guru, hasil observasi pembelajaran dan hasil angket isian siswa.

\section{HASIL PENELITIAN}

Penguasaan Konsep Siswa

Data yang dianalisis untuk penguasaan konsep siswa adalah hasil skor tes awal (Pretes) dan skor hasil tes akhir (Postes).Peningkatan penguasaan konsep yang dicapai siswa dalam Pretes dan Postes dapat dilihat pada gambar grafik berikut:

memperoleh gambaran tentang

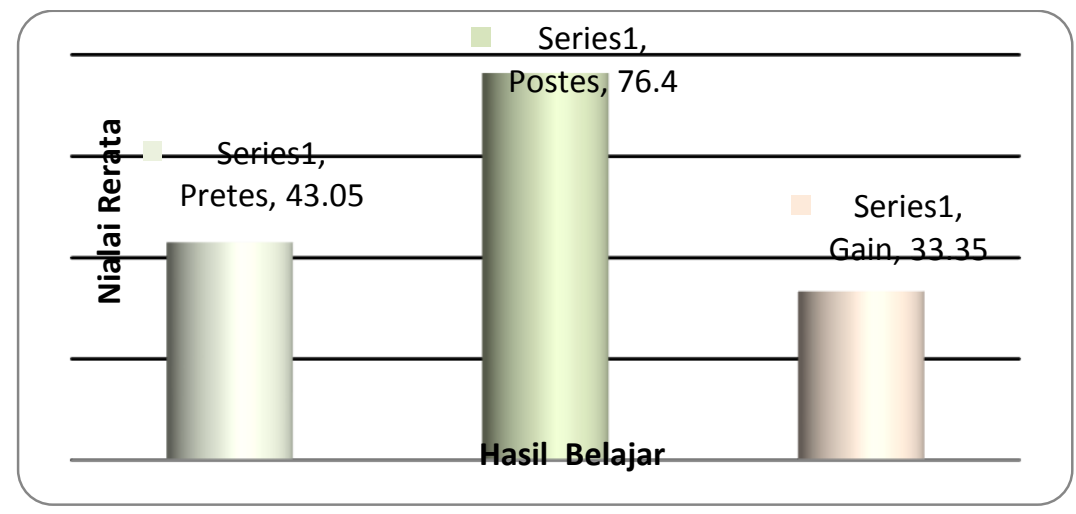

Gambar 1. Grafik Perbandingan Peningkatan Penguasaan Konsep

Berdasarkan data menunjukkan adanya masing kelompok yang akan diuji. Hasil perbedaan yang signifikan dalam pengujian uji $F$ diperoleh nilai $F_{\text {hitung: 1,68 }}$ peningkatan penguasaan konsep yang $<$ dibandingkan nilai $\mathrm{F}_{\text {tabel }}=1,70$, dicapai siswa. Berdasarkan hasil sehingga dapat disimpulkan bahwa pengolahan data diperoleh bahwa data pasangan kelompok nilai yang akan hasil belajar Pre Tes, dan Pos Tes dianalisis adalah homogen.

berdistribusi normal pada taraf signifikan Jumlah kelompok kemampuan ada 0,05. Untuk melihat homogenitas tiga, kelompok tinggi ditempati oleh siswa pasangan kelompok nilai yang akan yang memiliki nilai rata-rata ulangan dianalisis dalam Hasil pengamatanan ini harian antara 7,50 $+0,84=8.34$ hingga dilakukan pengujian homogenitas varians 10, kelompok sedang ditempati oleh siswa menggunakan uji F, yaitu dengan cara dengan nilai rata-rata ulangan harian < membandingkan varians dari masing- 8,34 hingga 7,50-0,84 =6,66; sedangkan 
kelompok rendah dengan nilai rata-rata harian $<6,66$. Rata-rata skor untuk ulangan

kelompok tinggi, sedang dan rendah terlihat pada tabel berikut:

Tabel 1. Rata-rata Skor Pre Tes, Pos Tes, Gain Kelompok Siswa Kemampuan Tinggi, Sedang dan Rendah

\begin{tabular}{|c|c|c|c|c|}
\hline \multirow{2}{*}{ Kelompok } & \multirow{2}{*}{$\mathrm{N}$} & \multicolumn{3}{|c|}{ Rata-rata Skor } \\
\cline { 3 - 5 } & & Pretes & Postes & Gain \\
\hline Tinggi & 4 & 9,5 & 14.5 & 5 \\
\hline Sedang & 28 & 9,4 & 13,7 & 4,30 \\
\hline Rendah & 8 & 9,5 & 13,4 & 3,90 \\
\hline
\end{tabular}

Tabel 1 di atas menunjukkan tingkat kemampuan siswa sebelum bahwa ada peningkatan penguasaan (Pretes) dan sesudah (Postes) dilakukan konsep baik pada masing-masing siswa dengan uji-t. Demikian juga data hasil maupun pada kelompok siswa sebelum pembelajaran siswa antar kelompok dan sesudah pembelajaran. Langkah berdasarkan tingkat kemampuan siswa selanjutnya adalah membandingkan rata- kelompok tinggi, sedang dan rendah rata nilai hasil pembelajaran berdasarkan diolah dengan uji-t.

Tabel 2. Ringkasan Uji-t untuk Hasil Belajar Sebelum (Pretes) dan Sesudah (Postes)

\begin{tabular}{|c|c|c|c|c|c|c|}
\hline Uji-t & Mean & $\mathrm{N}$ & $\mathrm{dk}$ & $\mathrm{T}_{\text {tabel }}$ & $\mathrm{T}_{\text {hitung }}$ & Kesimpulan \\
\hline $\begin{array}{l}\text { Pretes } \\
\text { Postes }\end{array}$ & $\begin{array}{l}9,4 \\
13,4\end{array}$ & $\begin{array}{l}40 \\
40\end{array}$ & 39 & 1,68 & 13,11 & Berbeda Signifikan \\
\hline $\begin{array}{l}\text { Kelompok Tinggi } \\
\text { Kelompok Sedang }\end{array}$ & $\begin{array}{l}5,8 \\
4,3 \\
\end{array}$ & $\begin{array}{l}4 \\
28 \\
\end{array}$ & 30 & 1,70 & 0,643 & Tidak Berbeda Signifikan \\
\hline $\begin{array}{l}\text { Kelompok Tinggi } \\
\text { Kelompok Rendah }\end{array}$ & $\begin{array}{l}5,0 \\
3,9\end{array}$ & $\begin{array}{l}4 \\
8\end{array}$ & 10 & 1,81 & 0,887 & Tidak Berbeda Signifikan \\
\hline $\begin{array}{l}\text { Kelompok Sedang } \\
\text { Kelompok Rendah }\end{array}$ & $\begin{array}{l}4,3 \\
3,9\end{array}$ & $\begin{array}{l}28 \\
8\end{array}$ & 34 & 1,68 & 0.484 & Tidak Berbeda Signifikan \\
\hline
\end{tabular}

Berdasarkan data pada Tabel 2 diketahui bahwa berdasarkan hasil uji-t, secara keseluruhan hasil belajar siswa sebelum dan sesudah pembelajaran menunjukkan perbedaan yang signifikan (pada taraf signifikansi $5 \%$ diperoleh, yaitu thitung: $13,11>t_{\text {tabel }}: 1,68(\mathrm{p}=0,000<0,05)$. Sedangkan hasil belajar berdasarkan tingkat kemampuan kelompok siswa: Kelompok Tinggi Kelompok Sedang $(\mathrm{p}=0,565>0,05)$; Kelompok

Tinggi - Kelompok Rendah $(\mathrm{p}=0,396$ > 0,05); dan Kelompok Sedang - Rendah) ( $\mathrm{p}=0,632>0,05)$ sebelum dan sesudah pembelajaran tidak menunjukkan perbedaan yang signifikan (pada taraf signifikansi $5 \%$ diperoleh $\left.t_{\text {hitung }}<t_{\text {tabel }}\right)$. 
Jadi model pembelajaran Sains dapat data Pretes dan ostes. Jumlah butir soal diterima secara merata untuk semua yang digunakan untuk mengukur kelompok siswa. penguasaan konsep asam basa ada 20

Peningkatan penguasaan konsep butir, sedangkan jumlah konsep yang siswa untuk setiap konsep diambil dari dipelajari siswa ada 5 konsep

Tabel 3. Skor Pre Tes dan Pos Tes untuk Tiap Konsep yang tercantum dalam Kegiatan

Inkuiri Berbasis Laboratorium

\begin{tabular}{|l|l|c|c|c|}
\hline \multicolumn{1}{|c|}{ No. Soal } & \multicolumn{1}{|c|}{ Definisi Konsep } & \multicolumn{1}{c|}{ Rata-rata } \\
\cline { 3 - 5 } $\begin{array}{l}1,2,3,8,9, \\
10,12,13,\end{array}$ & $\begin{array}{l}\text { Asam mempunyai sifat masam, dapat diuji dengan } \\
\text { indikator; Basa mempunyai sifat kelat, licin pada tangan, } \\
\text { dapat diuji dengan indikator; Netral mempunyai rasa } \\
\text { tidak masam atau basa, dapat diuji dengan indikator; dan } \\
\text { Indikator zat petunjuk sifat larutan asam, basa atau netral }\end{array}$ & 3,13 & 5,93 & 2,80 \\
\hline $3,4,5,6$, & $\begin{array}{l}\text { Reaksi asam dengan basa menghasilkan zat } \\
\text { baru, diuji dengan indikator bersifat netral. }\end{array}$ & 3,10 & 3,88 & 0,07 \\
\hline $7,17,18$ & $\begin{array}{l}\text { Reaksi asam dengan karbonat menghasilkan } \\
\text { zat baru dan menghasilkan gas karbon } \\
\text { dioksida }\end{array}$ & 1,10 & 1,43 & 0,33 \\
\hline 16,19 & $\begin{array}{l}\text { Reaksi asam dengan logam menghasilkan } \\
\text { zat baru dan gas hidrogen }\end{array}$ & 1,25 & 1,63 & 0,38 \\
\hline 20 & $\begin{array}{l}\text { Reaksi basa dengan logam menghasilkan zat } \\
\text { baru dan gas hidrogen }\end{array}$ & 0,85 & 0,85 & 0 \\
\hline \multicolumn{1}{|c|}{ Rata-rata } & 1,88 & 2,74 & 0,16 \\
\hline
\end{tabular}

Data di atas menunjukkan bahwa ada 4 konsep yang mengalami peningkatan. Peningkatan tertinggi yaitu sebesar 2,80 (31,11\%) diperoleh pada konsep Pengenalan Sifat Asam dan Sifat Basa. Ada 1 konsep yang tidak mengalami peningkatan (tetap), yaitu Reaksi Basa dengan Logam 0,00 (0,00\%).

\section{Keterampilan Berpikir Kreatif}

Butir-butir soal yang digunakan dalam penelitian ini selain digunakan untuk mengukur penguasaan konsep siswa, juga digunakan untuk mengukur peningkatan keterampilan berpikir kreatif siswa. Indikator keterampilan berpikir kreatif yang diukur disesuaikan dengan keterampilan berpikir kreatif yang dikembangkan dalam model pembelajaran asam basa. Indikator keterampilan berpikir kreatif ini meliputi: membangkitkan keingintahuan dan hasrat untuk tahu, memandang informasi yang sama dari sudut pandang yang berbeda, meramal dari informasi yang terbatas, memilih halhal yang mungkin tidak relevan, dan 
membangun di atas pengetahuan yang kreatif diolah untuk menentukan telah ada pada siswa. peningkatan keterampilan berpikir kreatif

Nilai Pre Tes dan Pos Tes untuk siswa seperti tertera pada tabel 4 berikut: setiap indikator keterampilan berpikir

Tabel 4 Skor Pre Tes dan Pos Tes untuk Keterampilan Berpikir Kreatif

\begin{tabular}{|c|c|c|c|c|}
\hline \multirow{2}{*}{ No. Soal } & \multirow{2}{*}{ Indikator } & \multicolumn{3}{|c|}{ Rata-rata } \\
\hline & & Pretes & Postes & Gain \\
\hline $1,2,4$ & Membangkitkan keingintahuan dan hasrat untuk tahu & 1,35 & 2,13 & 0,78 \\
\hline 7,16 & $\begin{array}{l}\text { Memandang informasi yang sama dari sudut pandang } \\
\text { yang berbeda }\end{array}$ & 1,05 & 1,40 & 0,35 \\
\hline $8,9,11,12$ & Meramal dari informasi yang terbatas & 1,10 & 2,23 & 1,13 \\
\hline $\begin{array}{l}3 \\
5,6,10,13 \\
14,15,17 \\
18,19,20\end{array}$ & $\begin{array}{l}\text { Memilih hal-hal yang mungkin tidak relevan } \\
\text { Membangun konsep di atas pengetahuan yang telah } \\
\text { ada pada diri siswa }\end{array}$ & $\begin{array}{l}0,75 \\
5,10\end{array}$ & $\begin{array}{l}0,80 \\
7,10\end{array}$ & $\begin{array}{l}0,05 \\
2,00\end{array}$ \\
\hline & Rata-rata & 1,87 & 2,73 & 0,86 \\
\hline
\end{tabular}

Tabel di atas menunjukkan bahwa proses sains yang diukur disesuaikan seluruh indikator keterampilan proses dengan keterampilan proses sains yang berpikir kreatif meningkat. Peningkatan dikembangkan dalam model pembelajaran terbesar adalah membangun konsep di atas asam basa. Indikator keterampilan proses pengetahuan yang sudah ada pada siswa sains ini meliputi: melakukan pengamatan 2,00 (20\%) sedangkan yang terendah (observasi), menafsirkan pengamatan adalah keterampilan memilih hal-hal yang (interpretasi), mengelompokkan mungkin tidak relevan yaitu sebesar 0,05 (klasifikasi) dan menerapkan konsep atau $(5 \%$.$) .$

\section{Keterampilan Proses Sains} prinsip. Nilai Pre Tes dan Pos Tes untuk Beberapa butir soal dalam Sains diolah untuk menentukan penelitian ini digunakan juga untuk peningkatan keterampilan proses sains mengukur peningkatan keterampilan siswa dan tertera pada tabel 5 proses sains siswa. Indikator keterampilan

Tabel 5. Skor Pre Tes dan Pos Tes untuk Keterampilan Proses

\begin{tabular}{|l|l|l|l|l|}
\hline \multirow{2}{*}{ No. Soal } & \multicolumn{1}{|c|}{ Indikator } & \multicolumn{3}{c|}{ Rata-rata } \\
\cline { 3 - 6 } & & Pretes & Postes & Gain \\
\hline 1,2 & Melakukan pengamatan (observasi) & 1,03 & 1,50 & 0,47 \\
\hline 3,4 & Menafsirkan pengamatan (interpretasi) & 1,10 & 1,43 & 0,33 \\
\hline $7,8,9,11,12,16,19,20$ & Mengelompokkan (klasifikasi) & 3,55 & 5,28 & 1,73 \\
\hline
\end{tabular}




\begin{tabular}{|c|c|c|c|c|}
\hline $5,6,10,13,14,15,17,18$ & Menerapkan konsep dan prinsip & 3,75 & 5,48 & 1,73 \\
\hline & Rata-rata & 2,36 & 3,42 & 1,06 \\
\hline
\end{tabular}

Tabel di atas menunjukkan bahwa seluruh indikator keterampilan proses sains meningkat. Peningkatan terbesar ada dua, yaitu menafsirkan pengamatan (interpretasi) dan menerapkan konsep atau prinsip sebesar 1,73 (21,62\%). Sedangkan yang terendah adalah keterampilan mengelompokkan, yaitu sebesar 0,33 $(16,5 \%)$.

\section{Hasil Observasi}

Hasil observasi menunjukkan bahwa guru telah melaksanakan kegiatan pembelajaran sesuai dengan tuntutan rancangan model pembelajaran. Walaupun demikian guru tidak terlalu terikat dengan apa yang tercantum dalam model pembelajaran, karena pertanyaanpertanyaan atau arahan kegiatan yang terdapat dalam

rancangan pembelajaran dapat dikembangkan oleh guru, sehingga dapat cepat dimengerti oleh siswa. Hasil observasi ini digunakan untuk mengakses aspek afektif yang dilakukan siswa selama kegiatan laboratorium berlangsung.

Tabel 6. Aspek Afektif Siswa Dalam Kegiatan Laboratorium

\begin{tabular}{|c|l|c|c|}
\hline \multirow{2}{*}{ No } & \multicolumn{1}{|c|}{ Aspek yang Diakses } & \multicolumn{2}{|c|}{ Deskripsi } \\
\cline { 3 - 4 } & & Ya & Tidak \\
\hline 1 & Kerjasama dalam kelompok & $\sqrt{ }$ & \\
\hline 2 & Aktivitas dalam berdiskusi & $\sqrt{ }$ & \\
\hline 3 & Kejujuran dalam menuliskan data & $\sqrt{ }$ & \\
\hline 4 & Kecermatan dalam bekerja & $\sqrt{ }$ & \\
\hline 5 & Menghargai pendapat teman & $\sqrt{ }$ & \\
\hline 6 & Mengelola kebersihan alat & \\
\hline
\end{tabular}

Selain aspek afektif, pengamatan juga keterampilan mengkonversi volume mengakses aspek psikomotor yang larutan dan (5) keterampilan mereaksikan dilakukan siswa selama kegiatan zat. Hasil observasi dapat diketahui bahwa laboratorium berlangsung diantaranya: (1) model pembelajaran berbasis inkuiri keterampilan mencampurkan zat; (2) laboratoium ini dapat mengembangkan keterampilan menggunakan indikator aspek afektif dan psikomotor siswa, dan kertas atau larutan; (3) keterampilan hal ini perlu menjadi perhatian bagi para mengukur volume larutan; (4) guru untuk melakukan penilaian secara 
khusus terhadap aspek afektif dan mengalami peningkatan (tetap), yaitu psikomotor dengan menyesuaian aspek- reaksi basa dengan logam 0,00 (0,00\%). aspek yang hendak diakses pada setiap kegiatan laboratoium.

\section{Peningkatan Keterampilan Berpikir Kreatif Siswa}

Hasil pengamatanan menunjukkan

\section{PEMBAHASAN}

\section{Peningkatan Penguasaan Konsep Siswa}

Berdasarkan Pre Tes dan Pos Tes hasil pembelajaran masing-masing siswa maupun kelompok, pemahaman konsep yang telah dipelajari siswa mengalami peningkatan dengan rata-rata skor sebesar $3,9(19,5 \%)$ dan skor rata-rata total 4,3 $(21,5 \%)$. Peningkatan pemahaman konsep terjadi pada siswa secara individu maupun untuk kategori kelompok tinggi, sedang maupun rendah. Peningkatan konsep terbesar pada kelompok tinggi sedangkan skor yang terkecil pada kelompok rendah.

Model Pembelajaraan Berbasis Inkuiri Laboratorium ini mencakup 5 konsep. Ditinjau dari perolehan skor ratarata dan gain dari pretes dan postes terdapat 4 konsep mengalami peningkatan, dan ada 1 konsep yang tidak mengalami peningkatan (tetap). Peningkatan tertinggi yaitu sebesar $2,80(31,11 \%)$ diperoleh pada konsep pengenalan sifat asam dan sifat basa. Ada 1 konsep yang tidak ada peningkatan keterampilan berpikir kreatif setelah implementasi model pembelajaran. Ada 5 indikator keterampilan berpikir kreatif, yaitu: membangkitkan keingintahuan dan hasrat untuk tahu, memandang informasi yang sama dari sudut pandang yang berbeda, meramal dari informasi yang terbatas, memilih hal-hal yang mungkin tidak relevan, dan membangun konsep di atas pengetahuan yang telah ada pada diri siswa. Rata-rata skor pretes dan postes untuk keterampilan berpikir mempunyai peningkatan. Oleh karena itu model ini dapat digunakan sebagai alternatif dalam melatih dan meningkatkan keterampilan berpikir kreatif siswa. Hal ini sesuai dengan pendapat Preissen dalam Costa (1985) bahwa secara umum berpikir dapat didefinisikan sebagai suatu proses kognitif, yaitu suatu kegiatan mental untuk memperoleh pengetahuan. Dalam proses berpikir terjadi kegiatan yang kompleks, reflektif dan kreatif. 


\section{Peningkatan Keterampilan Proses Sains Siswa}

Hasil Hasil pengamatanan ini menunjukkan bahwa ada peningkatan keterampilan proses sains setelah implementasi model pembelajaran. Ada 4 indikator keterampilan proses sains, yaitu: melakukan pengamatan (observasi), mengelompokkan (klasifikasi), menafsirkan pengamatan (interpretasi) dan menerapkan konsep atau prinsip. Pembelajaran IPA yang bertolak dari konsep pada umumnya akan lebih efektif bila diselenggarakan melalui model pembelajaran yang termasuk rumpun pemrosesan informasi. Model pemrosesan informasi bertitik tolak dari prinsipprinsip pengolahan informasi yang diterima individu. Model ini menjelaskan cara individu memberi respon yang datang dari lingkungannya, yakni dengan cara mengorganisasi data, memformulasi masalah, membangun konsep dan rencana pemecahan masalah serta menggunakan simbol-simbol verbal dan non-verbal. (Joyce \& Weil, 1992). Ditinjau dari keterampilan proses sains yang terdiri dari sejumlah keterampilan yang satu sama lain sebenarnya tidak dapat dipisahkan, karakteristik keterampilan proses sains klasifikasi merupakan keterampilan proses sains berupa penggolongan pola yang sudah ada (Rustaman,1995).

\section{KESIMPULAN}

1. Model pembelajaran yang disusun dapat meningkatkan penguasaan konsep siswa. Penguasaan konsep tertinggi yang dicapai siswa adalah sifat-sifat larutan asam basa, terendah adalah konsep reaksi basa dengan logam.

2. Model pembelajaran yang disusun dapat meningkatkan keterampilan berpikir kreatif siswa. Keterampilan berpikir kreatif tertinggi setelah implementasi model pembelajaran adalah membangun konsep di atas pengetahuan yang sudah ada pada diri siswa, sedangkan yang terendah adalah memilih hal-hal yang mungkin tidak relevan.

3. Model pembelajaran yang disusun dapat meningkatkan keterampilan proses sains. Peningkatan tertinggi terjadi pada indikator menafsirkan pengamatan (interpretasi) dan menerapkan konsep atau prinsip, 
sedangkan terendah pada indikator mengelompokkan (klasifikasi).

\section{SARAN}

1. Untuk mengatasi waktu pembelajaran yang dirasakan kurang dalam melaksanakan model pembelajaran, guru hendaknya mengatur bagianbagian pembelajaran tertentu yang dapat dikerjakan siswa di luar jam kelas.

2. Keterampilan berpikir kreatif dan keterampilan proses sains sebaiknya dikembangkan guru dengan menggunakan pokok bahasan lainnya.

\section{DAFTAR PUSTAKA}

Anonim. 2003. Pendekatan Kontekstual. Direktorat Pendidikan Lanjutan Pertama. Direktorat Jenderal Pendidikan Dasar dan Menengah. Depdiknas. Jakarta.

Arikunto, S. 1996. Dasar-Dasar Evaluasi Pendidikan. Bumi Aksara. Yogyakarta

Colburn, Alan. 2000. An Inquiry Primer Science Scope. March 2000.

Costa, Arthur L .1985. Developing Minds,A Resource Book for Teaching Thinking. Association for Supervision and Curriculum Development. Alexandria. Virginia Dahar, R.W. 1996. Teori-Teori Belajar. Erlangga. Jakarta

Depdiknas. 2003. Kurikulum2004, Standar Kompetensi, Mata Pelajaran Sains, Sekolah
Menengah Pertama, dan Madrasah Tsanawiyah. Depdiknas. Jakarta.

Hofstein, Ari and Lunetta. Vincent N. 1982. The Role of Laboratory in Science Teaching: Negleted Aspect of Research". Review of Educational Research. 52(2),201 207.

Indrawati. 2000. Model-Model Pembelajaran IPA. PPPG IPA. Bandung

Joyce, Bruce and Weil, Marssha, 1992. Models of Teaching. Prentice Hall, Inc. New Jersey

M. Amin. 1987. Mengajarkan Ilmu Pengetahuan Alam (IPA) DenganMenggunakan Metode "Discovery" dan "Inquiry". Proyek Pengembangan Lembaga Pendidikan Tenaga Kependidikan, Direktorat Jenderal Pendidikan Tinggi. Depdikbud. Jakarta:

Nancy Susianna. 2003. Model Pembelajaran Berbasis Kegiatan Laboratorium Sebagai Wahana Pendidikan Siswa SLTP Pada Pokok Bahasan Materi. Tesis PPS UPI Bandung: Tidak Diterbitkan.

Sukarno, Kertiasa N, Hadiat, Padmawinata D. 1977. DasarDasar Pendidikan Science. Bhratara. Jakarta

Sund, R.B, dan Trowbridge, Leslie W. 1973. Teaching Science By Inquiry In The Secondary School Second Edition. Charles E.Merill Publishingn Company. USA 